\title{
○奥村 重（嵫賀女子短期大学）
}

福井弥生, 畠山絹江（京都女子大学家政学部造形学科)

林仁美（成安造形短期大学）

A Study of the Posture and Consciousness in Putting on Shoes.

Sumire OKUMURA. (Siga Women's Junior Coll.)

Yayoi FUKUI. Kinue HATAKEYAMA. (Kyoto Women's Univ. Econo.)

Hitomi HAYASHI. (Seian coll. Art and Design.)

\section{1 はじめに}

私達は、前報においてヒールの高さの異なる靴 着用による、姿勢の変化を険討するために、重心 位置を娜定し、シルエッター写真から重心と桨勢 の関係について考察した。

本報では、ヒール高の違いによる姿勢の特徵を 険討するために、裸足時と靴着用時におけるシル エッター写真の撮影および計测を行った。また。 被験者の姿势に関する意識と、シルエッター写真 からの身体計測值との関連についても、険討を加 えた。

\section{2 方法}

被験者は、18〜21歳の女子学生 118名である。

資料は、これらの被験者の裸足時と靴着用時の シルエッター写真からの読み取り值45項目、およ び直接法で得た足部計测值19項目と、靴と等勢に 関する意識についての、アンケート調査結果であ る。

計湖時期は、1994年 5 月〜 6 月である。

シルエッター写真撮影の条件、計测方法は、前 報と同様である。

\section{3 蛣果および考察}

\section{1 計测值}

裸足時、ヒール高 $3 、 5 、 7 \mathrm{~cm}$ の相隣なる平均 值の差の険定を行った結果、厚径項目、高径項目
に認められ、裸足と $3 \mathrm{~cm} 、 3 \mathrm{~cm}$ と $5 \mathrm{~cm}$ 間に顕著で あり、これらからヒール高の違いによる、姿勢の 変化がうかがえる。

ヒール高別にシルエットの変化を見ると、ヒー ルが高くなるに従って、胸部の前径は大きくなり 腹部の前径は減少して、反身体の傾向になること が分かった。

体型別にみると、肥満型ではヒール高が $3 \mathrm{~cm}$ ら $5 \mathrm{~cm}$ と高くなるに従い、前径の比率が大となり、 特に下腿部において他の体型とは異なる様相を示 した。

\section{2 主成分分析}

勢の要因に奇与すると思われる26項目に縮的 して、主成分分析をした結果、ヒール高別には大 きな差はなく、第 1 因子は「体の大きさを表す因 子」、第 2 因子は「側面から見た前径の因子」、 第 3 ・第 4 因子は「前面・側面のシルエットを表 す因子」と解积できる。

体型別に因子得点を求めた結果、第 3 因子は体 型により㩆著な差がみられ、体型に左右される因 子と考えられる。

\section{3 アンケート結果}

姿勢に関する意識についてのアンケート結果で は、姿势についての関心は高く、その重視項目と して腹部の出方、脊柱の湾曲、ウエストのくびれ、 
大腿部の太さなどが揚げられた。

被験者の姿勢に対するイメージの構造を探るた めに、これらのアンケート結果を、数量化理論III 類により分析した結果、第 1 は頭部、肩部、胸部 腹腰部、下肢部にわたる姿勢のイメージ用語に、 大きいカテゴリーウエイトを示し、「身体のスタ イル全体のイメージ」の因子、第 2 は腹部の出方、 殿部の突出、頸の長さ、太さ、ウエストのくびれ、 脚の湾曲に高く、「女性らしい身体シルエット」 の因子、第 3 は胸部・腹部の大きさ、出方、ウェ ストのくびれ、下肢部の太さ、長さにウエイトが
高く、「若い女性の気にする身体形態のイメージ」 の因子と解积できる。

姿勢に対する意識に及ぼす要因としての計測項 目をみるために、アンケート結果と計测值の分散 分析をした結果、殆どの高径項目と矢状径項目に 有意差がみられた。

\section{参考文葫}

1)福井弥生、畠山綟江、奥村 董 : 靴着用時の姿 勢に関する考察、日本人間工学会関西支部大会 発表要旨集(1994.11).
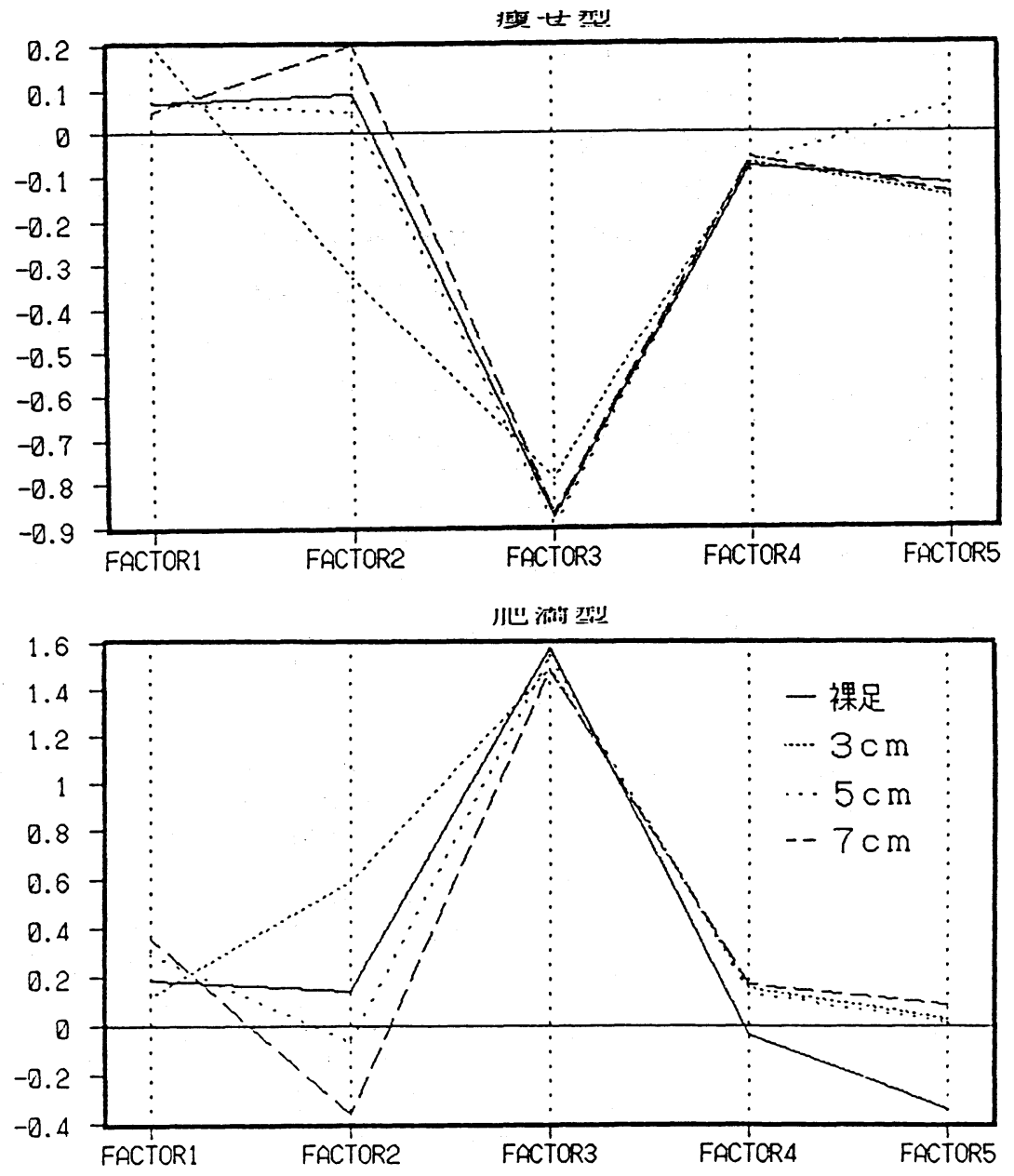

因子得点によるヒール高別比較 